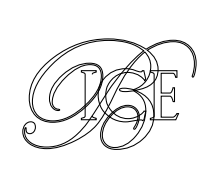

\title{
LA BALANZA COMERCIAL AGROALIMENTARIA EN 2016
}

Este artículo analiza la evolución de los principales sectores y mercados agrarios durante el año 2016 así como los factores más importantes que determinan el comportamiento de nuestra balanza agroalimentaria.

Se ha incluido el análisis sectorial de los productos de los veinticuatro primeros capítulos del arancel.

Palabras clave: importaciones, exportaciones, comercio exterior, agricultura, España, 2016.

Clasificación JEL: Q10, Q17.

\section{Evolución general}

De acuerdo con los datos de comercio exterior (Cuadro 1), la balanza comercial agroalimentaria, que comprende los 24 primeros capítulos del arancel, ha registrado en 2016 un superávit de más de 11.169 millones de euros y una ratio de cobertura de 133,5 por 100 . Se trata de los mayores valores registrados desde el año 2002, que en los últimos dieciséis años ha contado con un saldo positivo en la balanza comercial. En el Gráfico 1 también se puede observar que esta evolución positiva, con un aumento de la divergencia entre

\footnotetext{
*Ministerio de Economía, Industria y Competitividad.

Versión de agosto de 2017.

Por limitaciones de espacio no se ha podido incluir el análisis sectorial de todos los productos de los 24 primeros capítulos del arancel, sino únicamente los cuadros relativos a su comercio exterior. La versión completa de la balanza agroalimentaria correspondiente a 2016 se encuentra en: $h t t p: / / w w w . c o m e r c i o . g o b . e s / e s-E S / c o m e r c i o-$ exterior/informacion-sectorial/agroalimentarios/estadisticas/ Paginas/estadisticas.aspx
}

las exportaciones y las importaciones a partir de 2007 , da lugar a un aumento progresivo del saldo.

El peso del comercio exterior de productos agroalimentarios sobre el total de bienes también muestra máximos en los diez últimos años, tanto en exportaciones como en importaciones.

Durante el año 2016, el comercio exterior de productos agroalimentarios se ha visto afectado por los hechos más relevantes que se indican a continuación:

- El 13 de abril de 2016 se firmó el Protocolo de exportación de frutas de hueso (melocotones y ciruelas) de España a China, que ha permitido a nuestro país ser el primero de la UE autorizado a exportar estas frutas a dicho país.

- Con la aprobación del certificado sanitario en agosto de 2016, México ha abierto la importación de carne de porcino $D$ 
CUADRO 1

EVOLUCIÓN DEL COMERCIO EXTERIOR ESPAÑOL DE PRODUCTOS AGROALIMENTARIOS

(Miles de euros)

\begin{tabular}{|l|l|l|l|c|c|c|}
\hline Año & Exportación & Importación & Saldo & $\begin{array}{c}\text { Cobertura } \\
\text { (\%) }\end{array}$ & \multicolumn{2}{|c|}{$\begin{array}{c}\text { \% sobre total mercancías } \\
\text { Exportación }\end{array}$} \\
\hline $\mathbf{2 0 0 2}$ & 20.690 .756 & 18.548 .848 & 2.141 .909 & 111,5 & 15,5 & 10,6 \\
$\mathbf{2 0 0 3}$ & 21.589 .711 & 18.963 .570 & 2.626 .141 & 113,8 & 15,6 & 10,2 \\
$\mathbf{2 0 0 4}$ & 21.953 .570 & 20.391 .814 & 1.561 .756 & 107,7 & 14,9 & 9,8 \\
$\mathbf{2 0 0 5}$ & 22.569 .690 & 22.088 .969 & 480.720 & 102,2 & 14,6 & 9,5 \\
$\mathbf{2 0 0 6}$ & 23.883 .309 & 22.697 .096 & 1.186 .213 & 105,2 & 14,0 & 8,6 \\
$\mathbf{2 0 0 7}$ & 25.861 .548 & 25.530 .201 & 331.346 & 101,3 & 14,0 & 9,0 \\
$\mathbf{2 0 0 8}$ & 27.811 .138 & 26.912 .110 & 899.028 & 103,3 & 14,7 & 9,5 \\
$\mathbf{2 0 0 9}$ & 26.520 .841 & 23.888 .612 & 2.632 .230 & 111,0 & 16,6 & 11,6 \\
$\mathbf{2 0 1 0}$ & 29.100 .551 & 25.753 .433 & 3.347 .118 & 113,0 & 15,6 & 10,7 \\
$\mathbf{2 0 1 1}$ & 32.168 .087 & 28.357 .730 & 3.810 .356 & 113,4 & 14,9 & 10,8 \\
$\mathbf{2 0 1 2}$ & 35.628 .140 & 29.225 .268 & 6.402 .872 & 121,9 & 15,8 & 11,3 \\
$\mathbf{2 0 1 3}$ & 37.195 .596 & 28.814 .872 & 8.380 .724 & 129,1 & 15,8 & 11,4 \\
$\mathbf{2 0 1 4}$ & 38.687 .873 & 29.636 .446 & 9.051 .427 & 130,5 & 16,1 & 11,2 \\
$\mathbf{2 0 1 5}$ & 42.057 .749 & 32.293 .044 & 9.764 .705 & 130,2 & 16,8 & 11,8 \\
$\mathbf{2 0 1 6}$ & 44.541 .734 & 33.372 .523 & 11.169 .211 & 133,5 & 17,5 & 12,2 \\
\hline Los datos correspondientes a 2016 son provisionales. & & & & \\
Fuente: elaboración propia con datos del Departamento de Aduanas e Impuestos Especiales. & & \\
\hline
\end{tabular}

española, siendo también España el primer país de la UE autorizado a exportar estos productos. Asimismo, en junio de 2016, Chile abrió el mercado para la carne de porcino española.

- En mayo de 2016, la Asamblea de la Organización Internacional de Epizootias (OIE) reconoció el nuevo estatus sanitario de España frente a la Encefalopatía Espongiforme Bovina (EEB), pasando a ser un país de riesgo insignificante, de conformidad con el Código Sanitario para los Animales Terrestres de la OIE. Este reconocimiento supone un impulso a las negociaciones con terceros países para alcanzar acuerdos sanitarios para la exportación de bovinos y sus productos.

- El sector de las aves, por otro lado, se ha visto afectado en la UE por un crecimiento en los casos detectados de influenza aviar de alta patogenicidad en instalaciones de aves domésticas, con las consiguientes repercusiones en materia de exportación, por verse alteradas las condiciones que han de ser acreditadas a la hora de exportar. Afortunadamente, España no se vio afectada por ningún caso de esta enfermedad durante el año 2016.

- Otro aspecto reseñable desde el punto de vista sanitario ha sido la Xylella fastidiosa. Tras la aparición de Xylella fastidiosa en octubre de 2014 y ante la alta probabilidad de que se estableciera en la UE esta bacteria, se prohibió la introducción en la UE de vegetales de una serie de especies, entre las que se encuentra el olivo (Olea europea). La Xylella fastidiosa es una bacteria con un amplio rango de $D$ 
hospedantes, que produce graves daños en los cultivos mediterráneos como los cítricos, la vid, los frutales de hueso o el olivo. El arranque es la medida a aplicar en caso de detección, con lo que el riesgo para nuestro olivar es grave.

- Entrada en vigor del Acuerdo de Estabilización y Asociación entre la Unión Europea y Kosovo, con fecha 1 de abril de 2016. Kosovo ya se beneficiaba de concesiones autónomas en sus exportaciones a la UE, que se han regularizado desde la óptica de la Organización Mundial del Comercio (OMC) con este acuerdo.

- Aplicación del Acuerdo de Asociación entre la UE y Ucrania desde el 1 de enero de 2016. Las preferencias comunitarias previstas en el acuerdo eran aplicadas por la UE desde 2014 en la forma de concesiones comerciales autónomas. Ahora, desde el inicio de 2016, mejora el acceso de los productos de la UE en el mercado ucraniano, lo que ha producido un aumento de las exportaciones españolas a este país en dicho año.

- El 30 de octubre de 2016 se firmó el Acuerdo Económico y Comercial Global (CETA) entre la Unión Europea y Canadá. En el sector agroalimentario, el CETA beneficiará a los productos españoles mediante la liberalización arancelaria, especialmente los productos transformados, cuyos aranceles son superiores a los productos frescos. Destaca en vinos la eliminación de aranceles y la inclusión de cláusulas que limitan las prácticas discriminatorias de los monopolios provinciales canadienses de vinos y licores.

- En agosto de 2016, el Órgano de Solución de Diferencias de la OMC ha dado la razón a la UE en el panel presentado contra
Rusia por el caso de la peste porcina africana (PPA). Como consecuencia de la aparición a principios de 2014 de casos de PPA en Polonia y Lituania, Rusia prohibió la importación de productos de porcino de toda la Unión Europea, algo contrario a las normas de la OMC, en particular las del Acuerdo sobre la Aplicación de Medidas Sanitarias y Fitosanitarias (Acuerdo SPS). Rusia debe adaptar su legislación y sus medidas al resultado del panel, para lo que dispone de un plazo que finaliza el 6 de diciembre de 2017.

- En la X Conferencia Interministerial de la OMC celebrada en Nairobi se acordó la eliminación de las subvenciones a la exportación, con aplicación inmediata en 2016. Si bien este hecho no tiene efectos directos en nuestras exportaciones, porque las restituciones por exportación en la práctica no se estaban utilizando, hay otros países que cada vez con mayor peso recurrían a este tipo de apoyos.

- Tras la decisión del Reino Unido de salir de la UE, de acuerdo con el resultado del referéndum celebrado el 23 de junio de 2016, se abre un período de incertidumbre en un mercado importante para España.

Las exportaciones agroalimentarias (Cuadro 2) supusieron en 2016, 44.542 millones de euros, y 33.293.780 toneladas. En relación con la exportación total de bienes (254.530 millones de euros), las exportaciones agroalimentarias significaron el 17,5 por 100 , superior en el 0,7 por 100 a la participación del año 2015 (16,8 por 100).

Con respecto al año 2015, se ha producido un aumento en valor de un 5,9 por 100 (2.484 millones de euros) y en volumen del 0,2 por 100 (82.981 toneladas). 


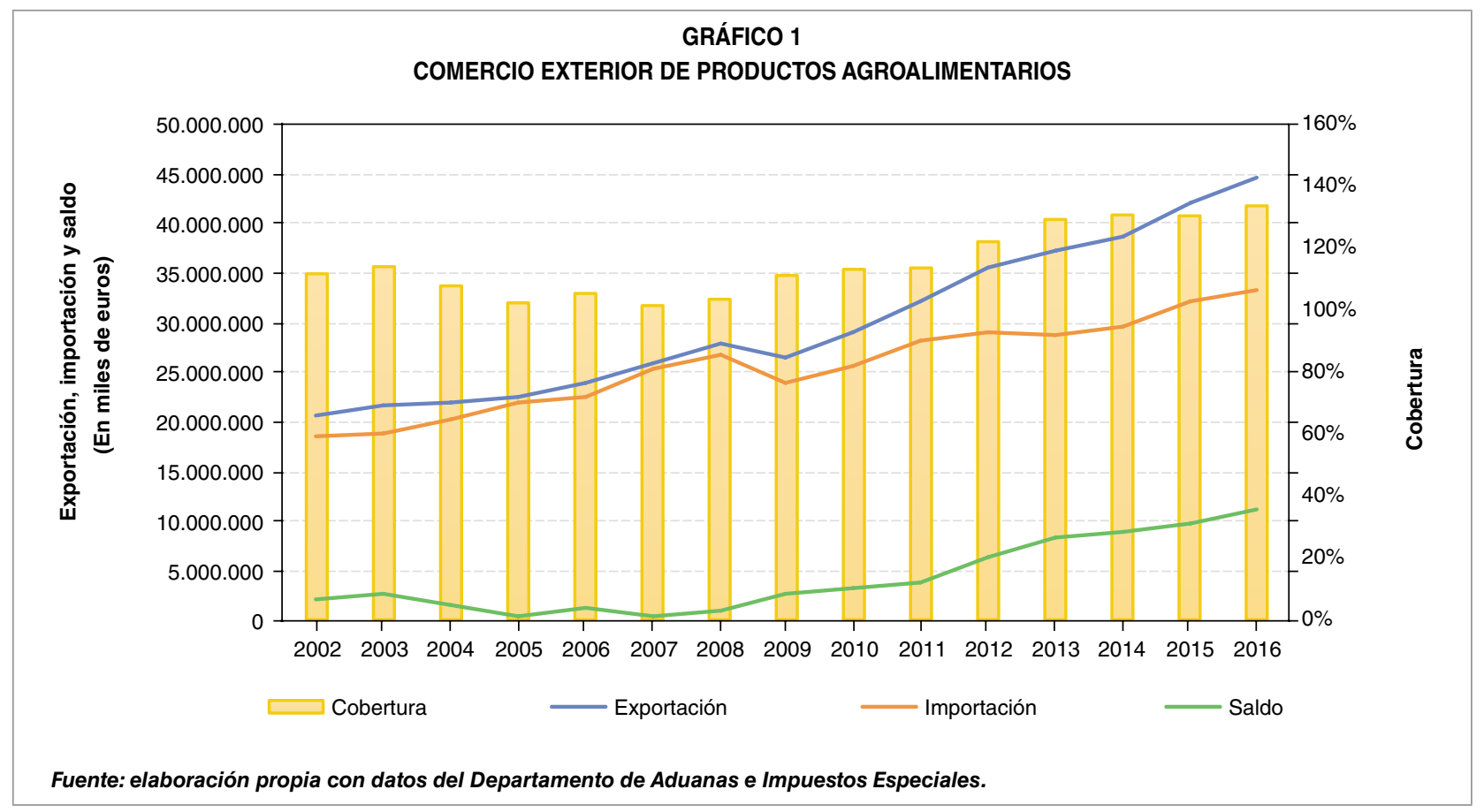

En volumen, hay ocho capítulos (uno menos que en 2015, 2014 y 2013 , e igual que en 2012) que superan el millón de toneladas de exportación y suponen el 81,1 por 100 del total exportado: 08 (frutas y frutos sin conservar), 07 (legumbres y hortalizas sin conservar), 22 (bebidas), 02 (carne y despojos comestibles), 20 (conservas y zumos vegetales), 15 (grasas y aceites animales o vegetales), 23 (residuos de la industria alimentaria) y 12 (semillas oleaginosas y plantas industriales).

En cuanto al valor, once capítulos (igual que en 2015, 2014 y 2013) han superado los mil millones de euros, suponiendo el 86,6 por 100 del total: capítulos 08 (frutas y frutos sin conservar), 07 (legumbres y hortalizas sin conservar), 02 (carne y despojos comestibles), 15 (grasas y aceites animales o vegetales), 22 (bebidas), 20 (conservas vegetales y zumos), 03 (pescados, crustáceos, moluscos), 19 (productos a base de cereales), 21 (preparaciones alimenticias diversas), 16 (conservas de carne o de pescado) y 04 (leche y productos lácteos y huevos).
La subida del volumen de las exportaciones se ha debido principalmente a los capítulos 02 (carnes y despojos comestibles), 15 (grasas y aceites animales o vegetales), 07 (legumbres y hortalizas sin conservar) y 17 (azúcar y productos de confitería), todos ellos con aumentos superiores a 100.000 toneladas. Proporcionalmente destacan en volumen, además del avituallamiento, los incrementos de los capítulos 17 (azúcar y productos de confitería), 02 (carne y despojos comestibles), 15 (grasas y aceites animales o vegetales), 14 (materias trenzables), 09 (café, té, yerba mate y especias) y 11 (productos de la molinería y malta), cada uno con un aumento superior al 10 por 100. Por otro lado, han disminuido las exportaciones en más de un 10 por 100 de los capítulos 10 (cereales) y 13 (jugos y extractos vegetales). Otros capítulos con reducción de las exportaciones son el 22 (bebidas), 12 (semillas oleaginosas y plantas industriales), 08 (frutas y frutos sin conservar), 23 (residuos de la industria alimentaria), 18 (cacao y sus $\triangleright$ 
preparaciones) y 04 (leche, productos lácteos y huevos). El tonelaje de los demás capítulos 1 a 24 del arancel ha aumentado.

Respecto del valor, destaca el incremento de las exportaciones en los capítulos 02 (carnes y despojos comestibles), 15 (grasas y aceites animales o vegetales), 07 (legumbres y hortalizas sin conservar), 03 (pescados, crustáceos, moluscos), 19 (productos a base de cereales) y 20 (conservas vegetales y zumos), todos con aumentos superiores a 100 millones de euros. También se observa aumento de la exportación en los demás capítulos, excepto en el 10 (cereales), 22 (bebidas), 08 (frutas y frutos sin conservar), 04 (leche, productos lácteos y huevos), 24 (tabaco y sus sucedáneos), y 14 (materias trenzables). Proporcionalmente, los productos con mayor aumento (superior al 10 por 100) en las exportaciones han sido los de los capítulos 17 (azúcar y productos de confitería), 15 (grasas y aceites animales o vegetales), 02 (carnes y despojos comestibles), 06 (plantas y flores), y 12 (semillas oleaginosas y plantas industriales). Han registrado descensos seis capítulos, uno de ellos en un porcentaje superior al 10 por 100 (-18,7 por 100), correspondiente a los cereales.

Las importaciones agroalimentarias (Cuadro 3) supusieron 33.373 millones de euros y 40.063.216 toneladas. En relación con la importación total española de bienes (273.284 millones de euros), el sector agroalimentario ha supuesto el 12,2 por 100 del valor total importado, muy similar (0,4 por 100 superior) al porcentaje de 2015 (11,8 por 100).

Con respecto al año anterior, y en términos de valor, en 2016 se ha producido un aumento del 3,3 por 100 de las importaciones agroalimentarias (1.079 millones de euros), debido fundamentalmente a los capítulos 03 (pescados, crustáceos y moluscos, con un aumento de 648 millones de euros), 08 (frutas y frutos sin conservar), 07 (hortalizas y legumbres) y 20 (conservas y zumos vegetales), cada uno con un incremento superior a 100 millones de euros. En términos porcentuales, los mayores aumentos se han producido, además del avituallamiento, en los capítulos 14 (materias trenzables), 03 (pescados, crustáceos y moluscos), 06 (plantas y flores), 11 (productos de la molinería y malta), 07 (hortalizas y legumbres) y 20 (conservas y zumos vegetales), todos con un incremento superior al 10 por 100 . Ha habido reducción de las importaciones, en ningún caso superior a 100 millones de euros, en los capítulos 23 (residuos de la industria alimentaria), 10 (cereales), 04 (leche, productos lácteos y huevos), 12 (semillas oleaginosas y plantas industriales), 16 (conservas de carne o de pescado), 24 (tabaco y sus sucedáneos), 01 (animales vivos) y 09 (café, té, yerba mate y especias).

En cuanto al volumen, se ha producido una subida del 2,1 por 100. Destacan los capítulos 10 (cereales), 15 (grasas y aceites), cada uno con un incremento superior a 100.000 toneladas. En términos porcentuales, además del avituallamiento, los mayores aumentos han tenido lugar en los capítulos 06 (plantas y flores), 14 (materias trenzables), 13 (jugos y extractos vegetales), 08 (frutas y frutos sin conservar), 15 (grasas y aceites) y 19 (productos derivados de cereales), con variaciones superiores al 10 por 100. Entre las disminuciones de las importaciones, superiores a 100.000 toneladas, se encuentran los capítulos 12 (semillas oleaginosas y plantas industriales) y 04 (leche, productos lácteos y huevos).

El esquema de nuestras importaciones es similar al de años anteriores. En volumen hay nueve capítulos que superan el millón de toneladas, uno menos que en los tres años $\triangleright$ 


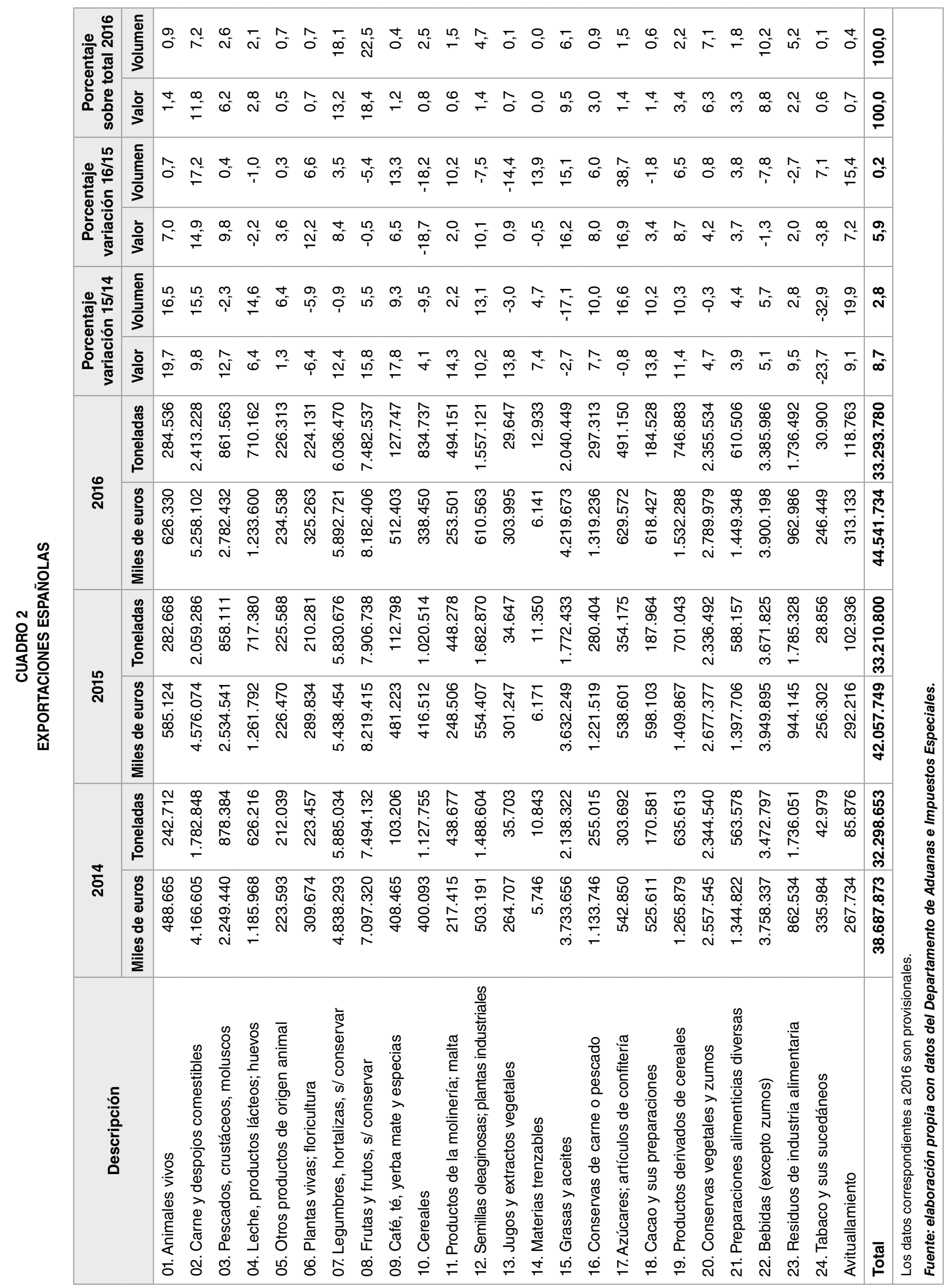




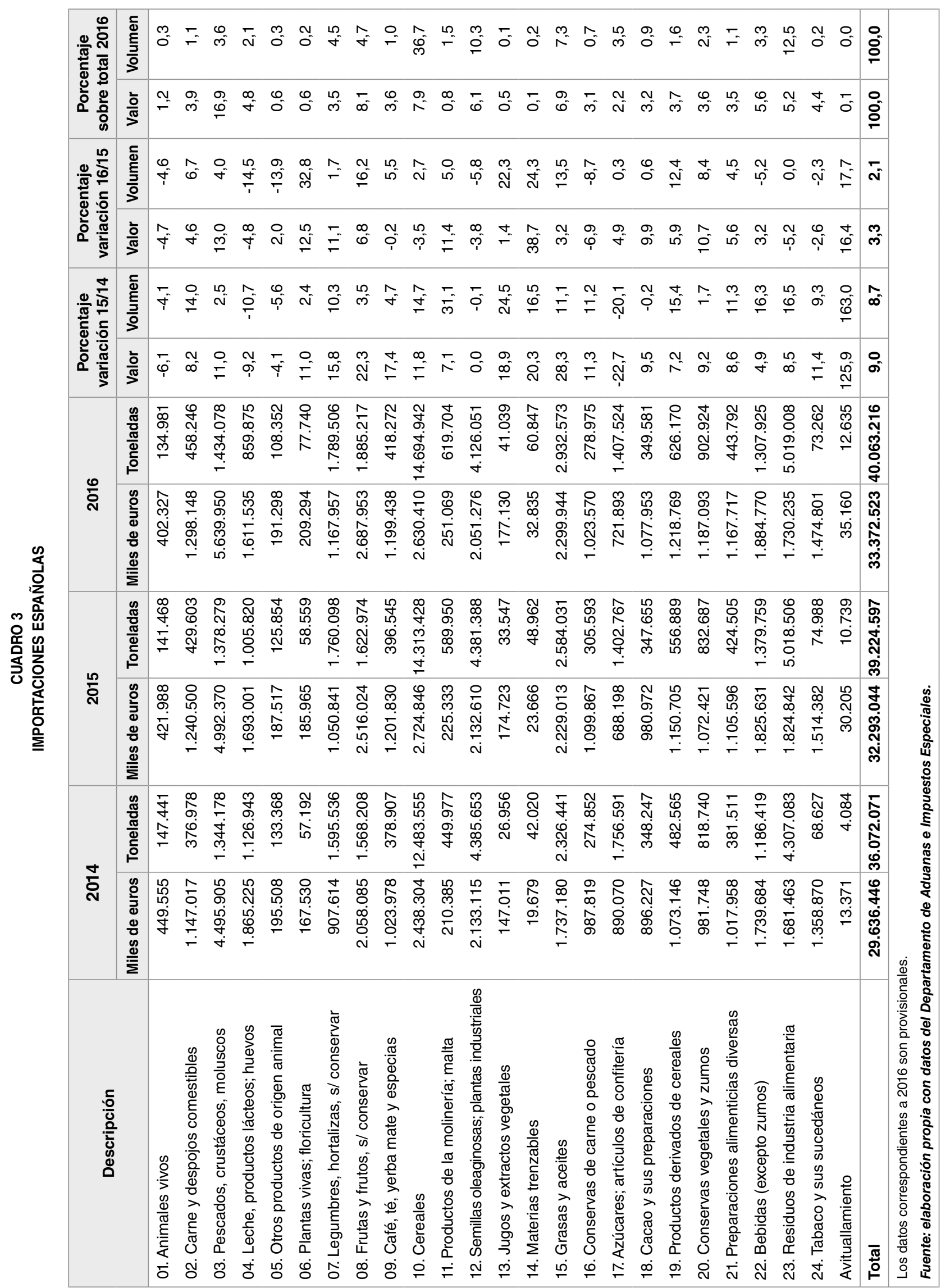


anteriores. Estos son, por orden de importancia: capítulos 10 (cereales), 23 (residuos industria alimentaria), 12 (semillas oleaginosas y plantas industriales), 15 (grasas y aceites animales o vegetales), 08 (frutas y frutos sin conservar), 07 (legumbres y hortalizas sin conservar), 03 (pescados, crustáceos y moluscos), 17 (azúcares, artículos confitería) y 22 (bebidas). Los cinco primeros suponen el 71,5 por 100 del total de las importaciones. Como se ha indicado, el principal capítulo es el de cereales, del que se han importado 14,7 millones de toneladas (36,7 por 100 del total).

En cuanto al valor, hay diecisiete capítulos que han superado los mil millones de euros, uno más que en 2015. El más relevante es el capítulo 03 (pescados, crustáceos y moluscos), del que se han importado 5.640 millones de euros y representa el 16,9 por 100 del total.

Por orden de importancia, los capítulos 03 (pescados, crustáceos y moluscos), 08 (frutas y frutos sin conservar), 10 (cereales), 15 (grasas y aceites animal o vegetales), 12 (semillas oleaginosas y plantas industriales), 22 (bebidas), 23 (residuos de la industria alimentaria), 04 (leche, productos lácteos y huevos), 24 (tabaco y sus sucedáneos), 02 (carne y despojos comestibles), 19 (productos derivados de cereales), 09 (café, té, yerba mate y especias), 20 (conservas y zumos vegetales), 07 (hortalizas y legumbres), 21 (preparaciones alimenticias diversas), 18 (cacao y sus preparaciones) y 16 (conservas de carne o de pescado). Todos ellos suponen el 93,9 por 100 del total.

Los capítulos cuya importación ha aumentado en 2016 son todos menos los capítulos 12 (semillas oleaginosas y plantas industriales), 04 (leche, productos lácteos y huevos), 22 (bebidas), 16 (conservas de carne y pescado), 05 (otros productos de origen animal), 01 (animales vivos) y 24 (tabaco y sus sucedáneos).

\section{Distribución geográfica del comercio exterior agroalimentario}

\subsection{Exportaciones por destino}

Los principales destinatarios de las exportaciones españolas son los demás países de la Unión Europea (UE). En el Cuadro 4 se puede observar un aumento de nuestras exportaciones a la UE en valor (3,8 por 100) acompañado de un descenso en volumen $(-1,1$ por 100$)$, representando el 77,5 por 100 de nuestras exportaciones totales en volumen $(78,6$ por 100 en 2015) y del 73,5 por 100 en valor (74,9 por 100 en 2015).

Considerados de manera individual, nuestros principales mercados en la UE son: Francia (16,2 por 100 en valor y 18,7 por 100 en volumen), Alemania (11,9 por 100 en vaIor y 13,2 por 100 en volumen), Italia (10,4 por 100 en valor y 7,4 por 100 en volumen), Portugal (9,4 por 100 en valor y 12,1 por 100 en volumen) y Reino Unido (8,6 por 100 en valor y 8 por 100 en volumen). Estos cinco países suponen el 59,5 por 100 de la exportación española en volumen y el 56,4 por 100 en valor.

Fuera de la Unión Europea superan la cuota del 1 por 100 del volumen China (2,3 por 100), Emiratos Árabes Unidos (2,2 por 100), EEUU (1,8 por 100) y Marruecos (1,2 por 100). En valor, superan el 1 por 100 de las exportaciones totales EEUU (3,9 por 100), China $(2,7$ por 100), Japón (1,7 por 100) y Suiza (1,3 por 100).

Otros mercados relevantes son los países que forman parte del Acuerdo de Libre Comercio de América del Norte (NAFTA) y los países euromediterráneos. Las exportaciones españolas a NAFTA suponen el 2,4 por $100 \mathrm{del}$ volumen y el 5,2 por 100 del valor total, y $\triangleright$ 
han aumentado con respecto a 2015 un 9,1 por 100 en volumen y un 10,1 por 100 en valor. Tres cuartas partes de estas exportaciones tienen como destino EEUU.
Nuestras exportaciones a los países euromediterráneos representan el 3,5 por 100 en volumen y el 2,6 por 100 en valor, y también han aumentado un 9 por 100 en volumen y un 6,6 por 100 en valor. $\triangleright$
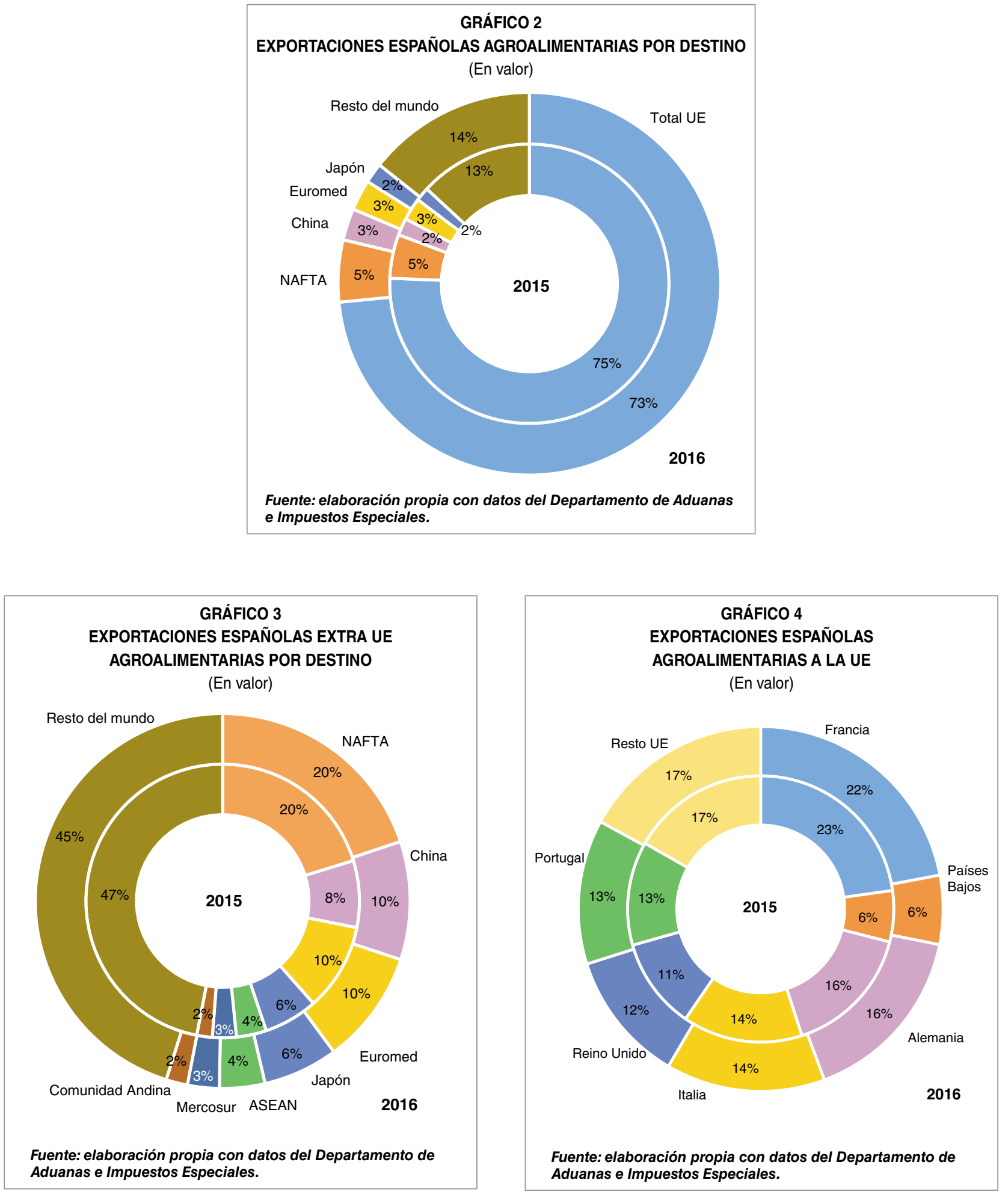


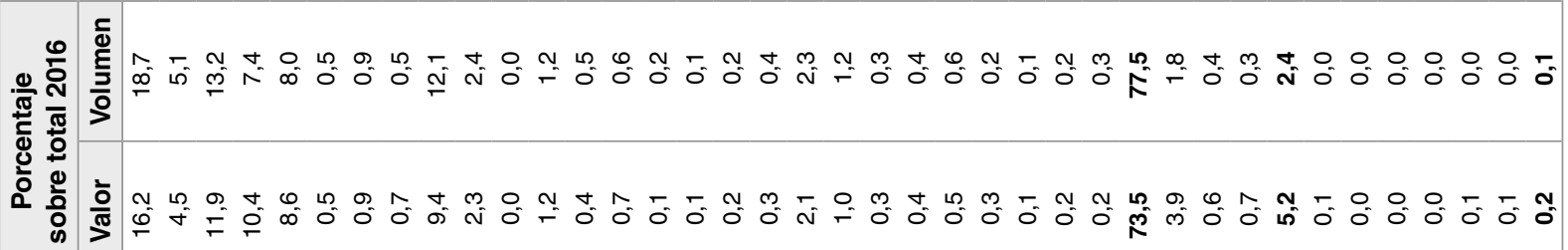

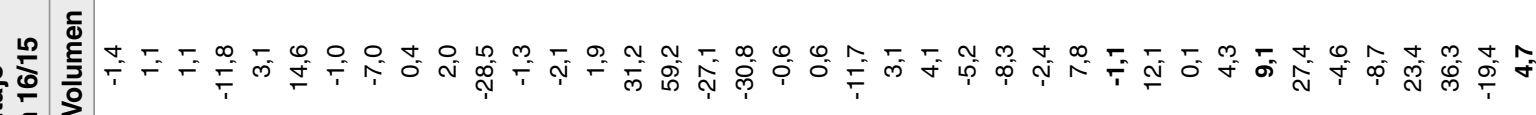

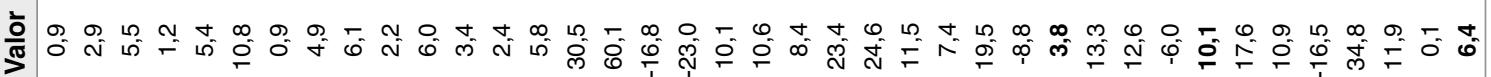

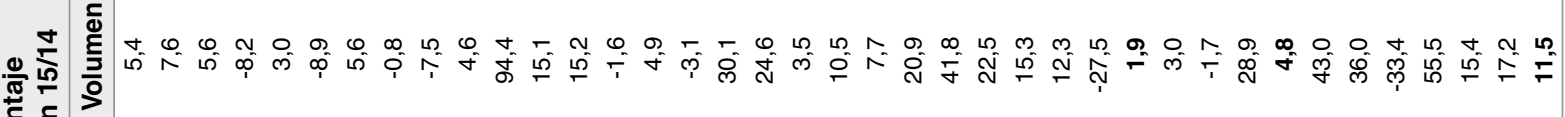

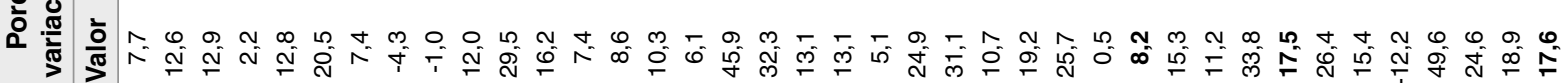

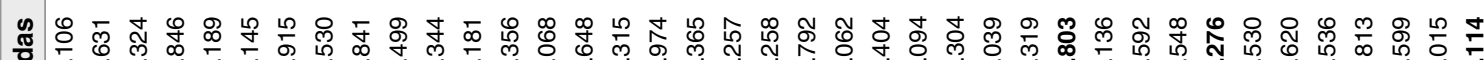

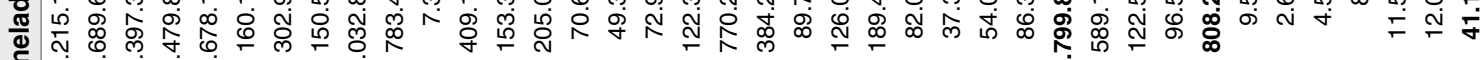
흐 นึ่

กำ

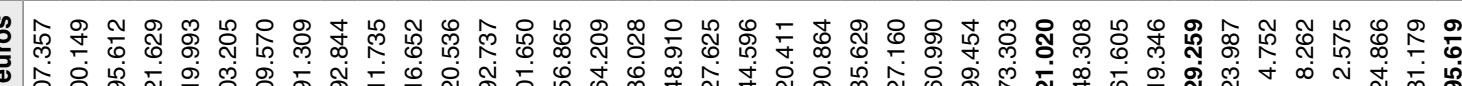

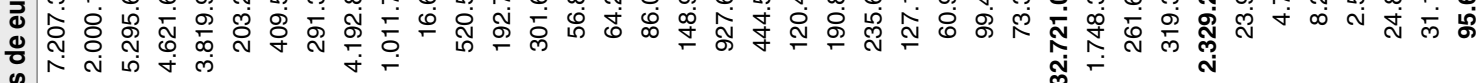

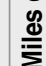

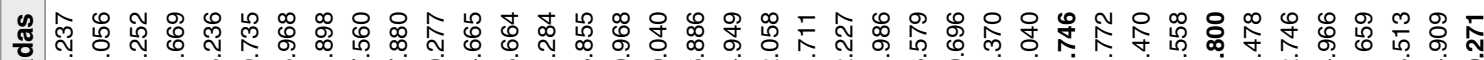

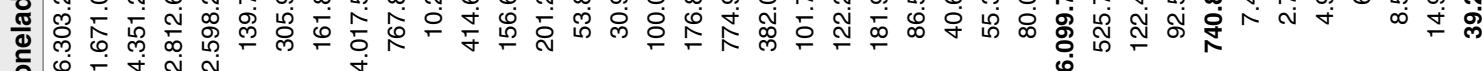
б。

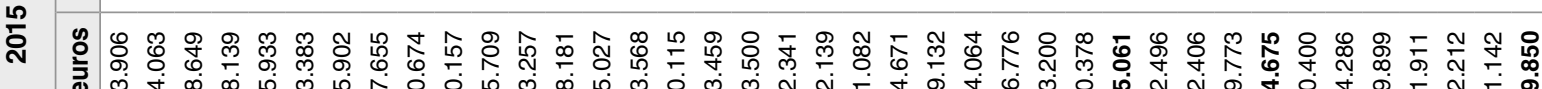

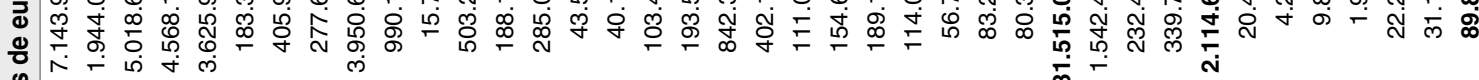

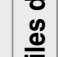

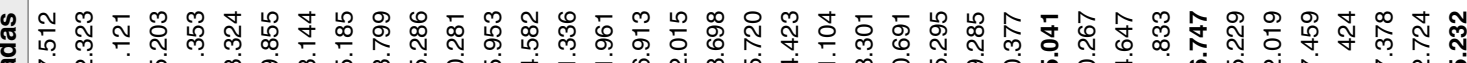

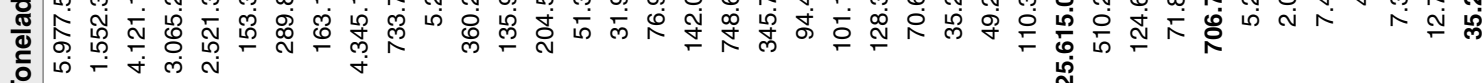
ㅎำ

กั่

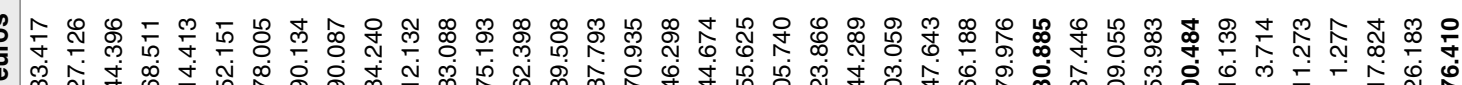

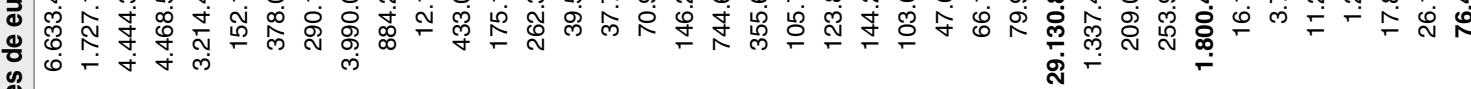
$\stackrel{\mathscr{D}}{\overrightarrow{\underline{\Sigma}}}$ 


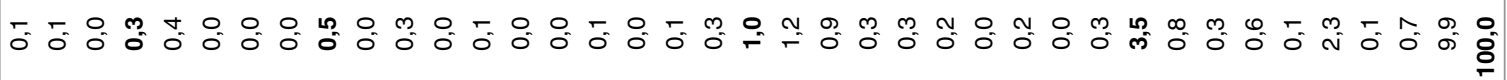

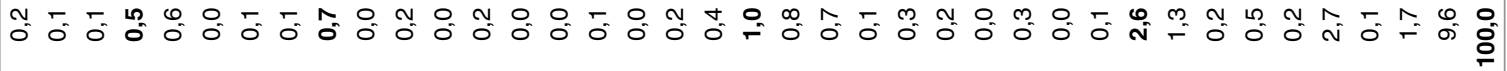

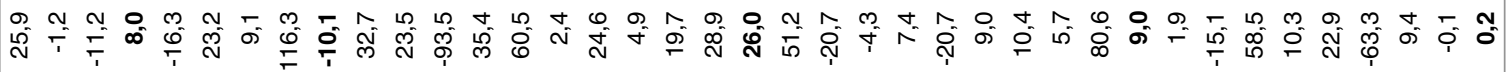

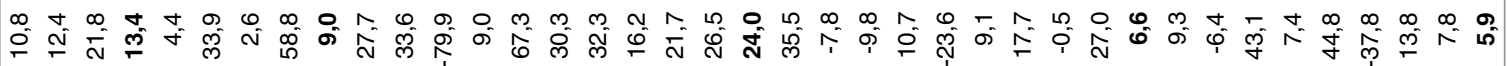

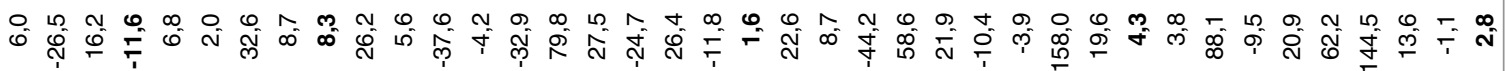

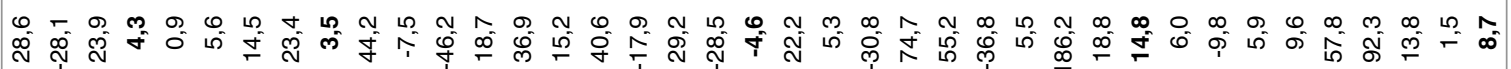
군 \&

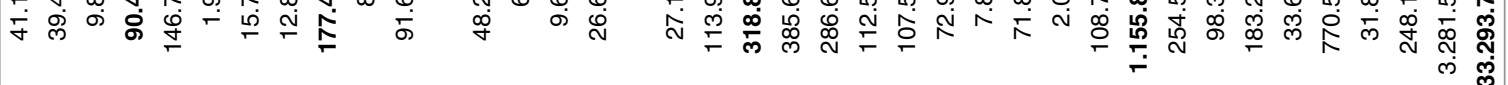

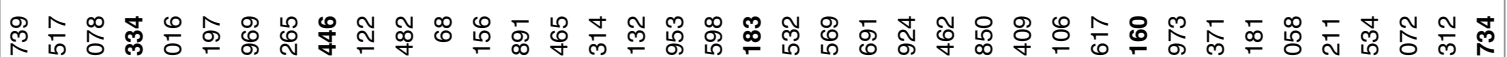

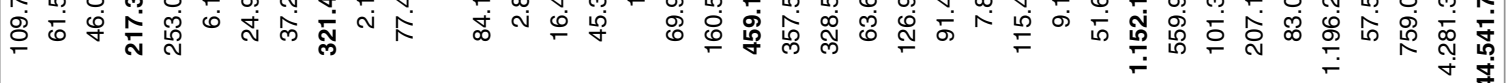

\& 仙

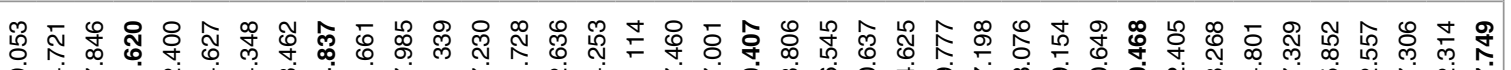

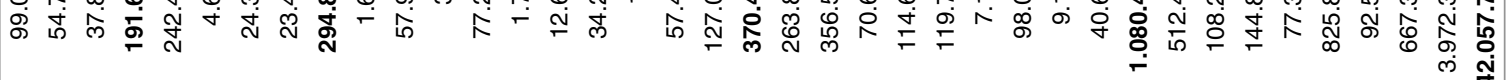

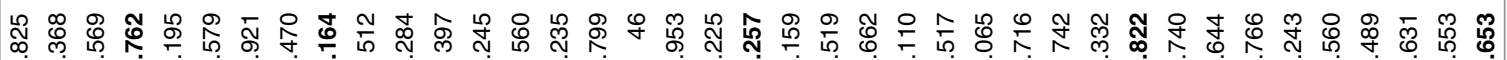

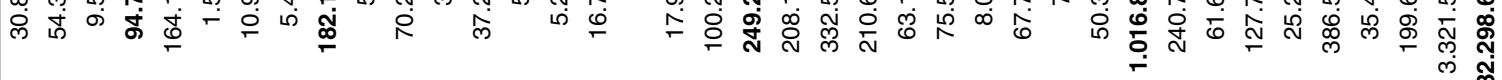

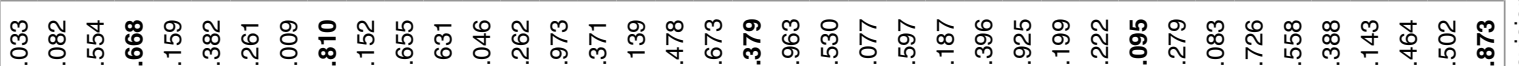

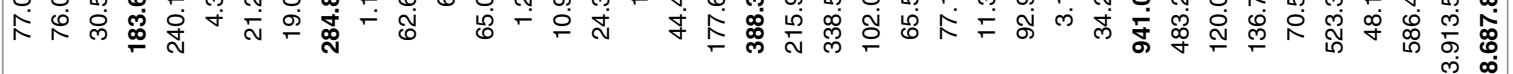




\subsection{Importaciones por origen}

Los principales proveedores de productos agroalimentarios (Cuadro 5) son también los demás países de la UE. En términos porcentuales sobre el total de 2015, representan en volumen el 53,6 por 100 (51,9 por 100 en 2015) y en valor el 55,3 por 100 (55 por 100 en 2015). Al comparar con las importaciones de 2015, y en términos porcentuales, aumentan en volumen $(5,5$ por 100$)$ y en valor $(4,1$ por 100).

Los principales proveedores europeos en términos de volumen son: Francia (más de siete millones de toneladas), Reino Unido (más de dos millones de toneladas), Portugal (más de 1,5 millones de toneladas), Países Bajos, Alemania, Rumania y Bulgaria (los cuatro con más de un millón de toneladas). En términos de valor, los principales proveedores son Francia, Alemania, Países Bajos, Portugal, Italia y Reino Unido, todos ellos con importaciones superiores a mil millones de euros, y suponen el 43,4 por 100 del valor total importado por España. Fuera de la Unión Europea, iguaIan o superan la cuota del 1 por 100 Ucrania (9,8 por 100), Brasil (7,1 por 100), Argentina (6,2 por 100), Estados Unidos (4,42 por 100), Indonesia (3,1 por 100$)$, Rusia (1,4 por 100$)$, Canadá (1,3 por 100) y Marruecos (1,3 por 100).

Por lo que respecta al valor, y al igual que el año pasado, sólo cinco países superan el 5 por 100: Francia (14,3 por 100), Alemania (8,1 por 100), Países Bajos (7 por 100), Portugal $(5,7$ por 100) y, fuera de la UE, Estados Unidos (5 por 100). Otros terceros países que superan el 1 por 100 son: Argentina (3,9 por 100), Brasil (3,8 por 100), Marruecos (3,5 por 100), Ucrania
(2,7 por 100$)$, China (2,3 por 100$)$, Indonesia (2,3 por 100), Ecuador (1,5 por 100), Perú (1,5 por 100), Vietnam (1,1 por 100), Chile (1 por 100) e India (1 por 100).

El siguiente grupo de países, por orden de importancia, es el Mercado Común del Sur (Mercosur). Al igual que en 2015, Mercosur mantiene la segunda posición entre los principales proveedores. En términos porcentuales sobre el total de 2016, Mercosur representa el 14,2 por 100 en volumen (15,3 por 100 en 2015) y el 8,3 por 100 en valor (8,9 por 100 en 2015). Las variaciones porcentuales respecto al año anterior indican un descenso en el volumen de las importaciones $(-5,7$ por 100$)$ y en el valor $(-4$ por 100). Brasil y Argentina continúan siendo los principales proveedores tanto en volumen (2,8 millones y de 2,5 millones de toneladas respectivamente) como en valor (1.261 millones de euros Brasil y 1.309 millones Argentina).

El tercer grupo de países proveedores es NAFTA, con el 5,9 por 100 del volumen y el 6,3 por 100 del valor total importado. Con respecto a 2015, las importaciones se han reducido ligeramente $(-0,2$ por 100 en volumen y $-2,2$ por 100 en valor). Igual que en el caso de las exportaciones, alrededor de las tres cuartas partes vienen de Estados Unidos.

También tienen cierta relevancia las importaciones de la Asociación de Naciones del Sudeste Asiático (ASEAN), con un 4,5 por 100 del volumen y un 4,4 por 100 del valor, y las de los países euromediterráneos (1,9 por 100 del volumen y 4,3 por 100 del valor). Asean ha aumentado considerablemente sus exportaciones en 2016 (10,8 por 100 en volumen y 8,6 por 100 en valor), mientras que los países Euromed las han reducido (-5,8 por 100 en volumen y $-2,7$ por 100 en valor). 

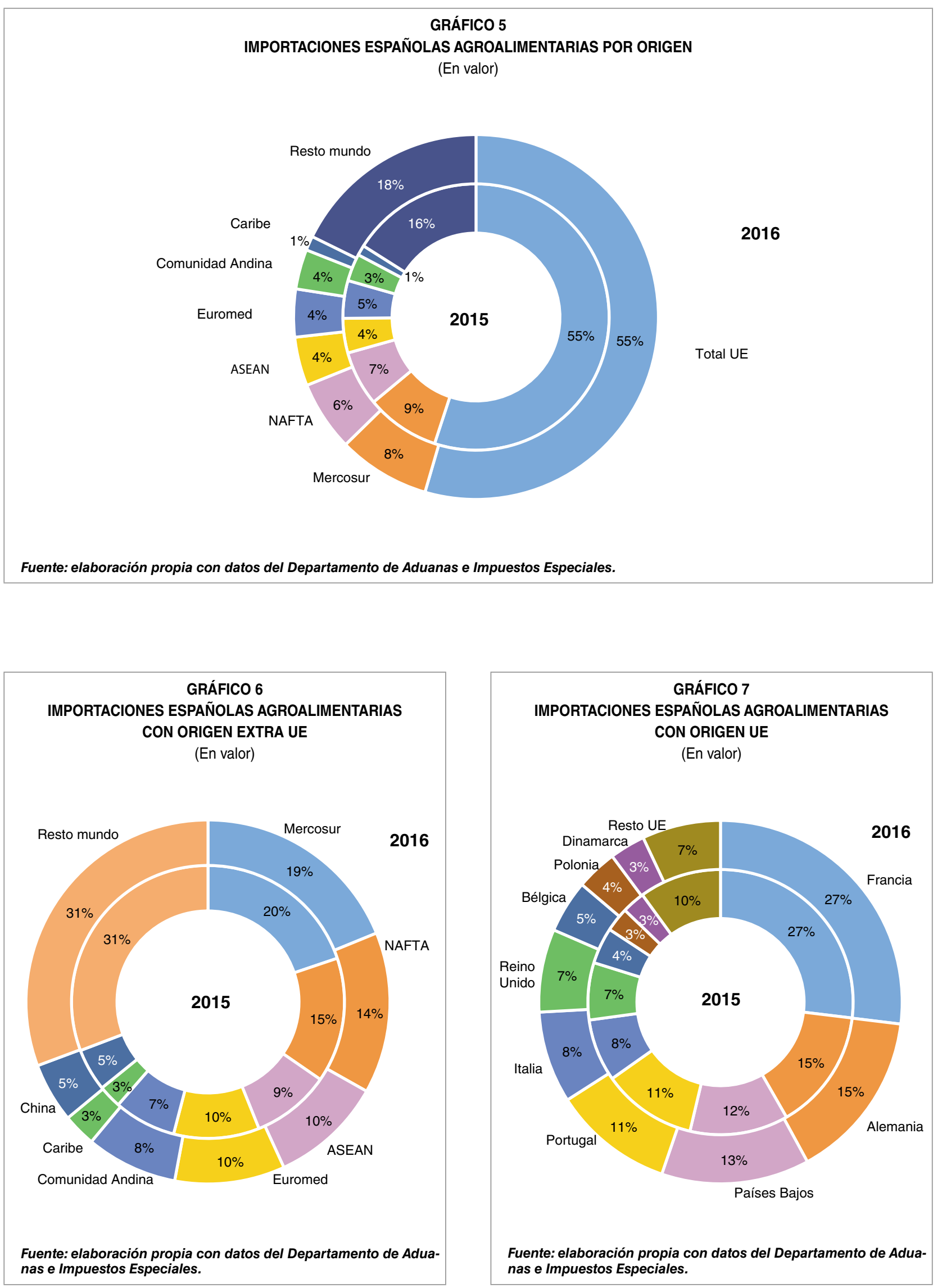


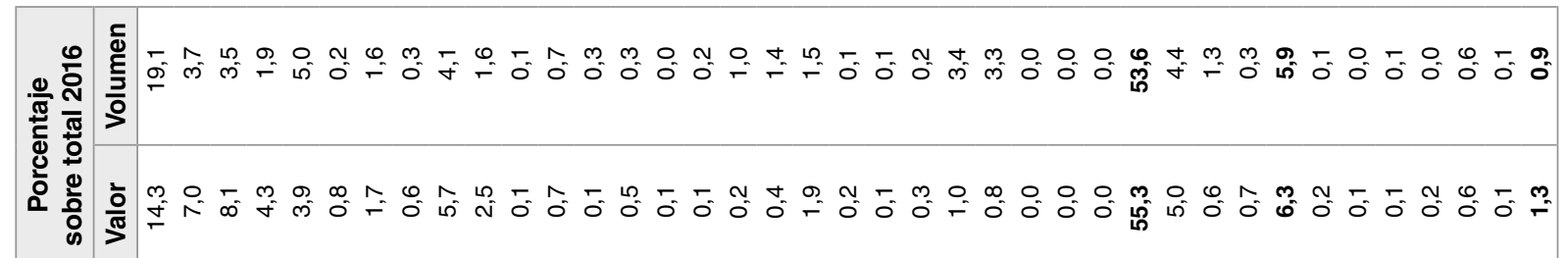

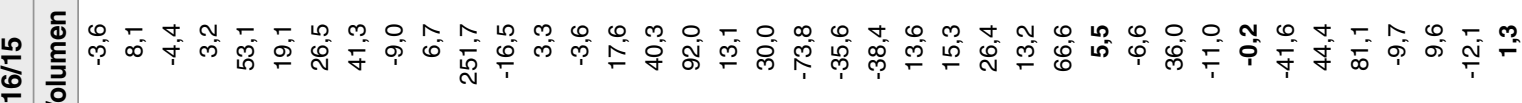

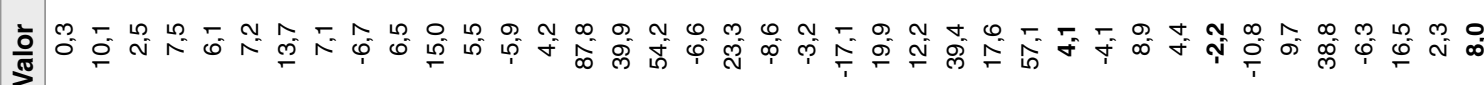

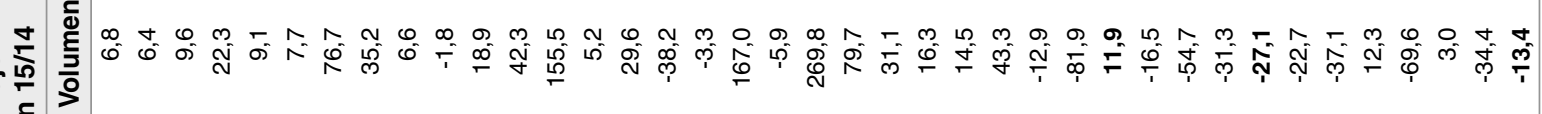

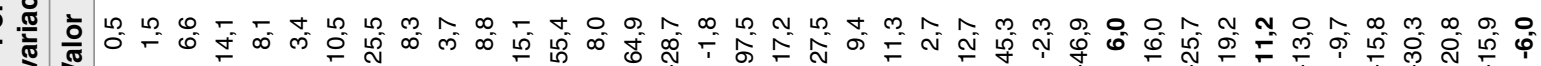

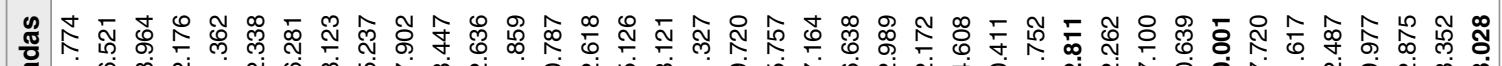

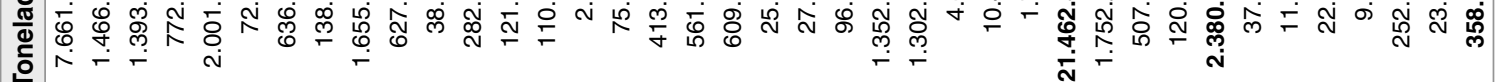

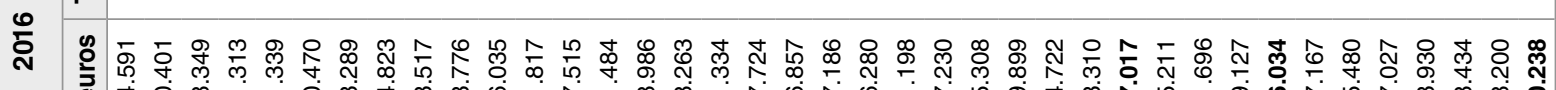

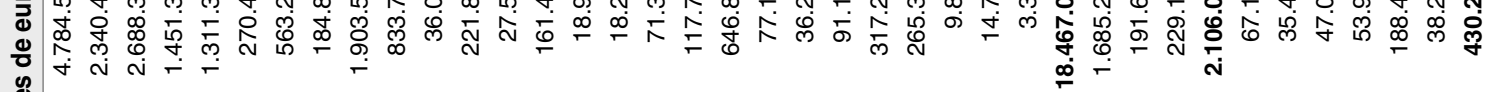

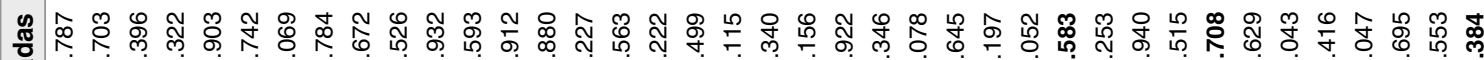

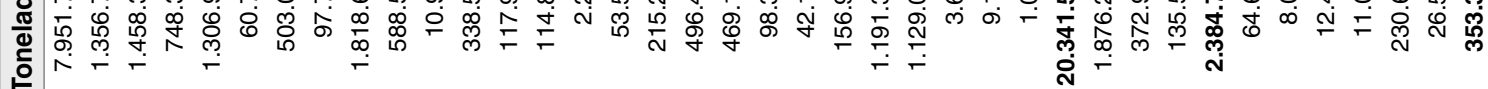

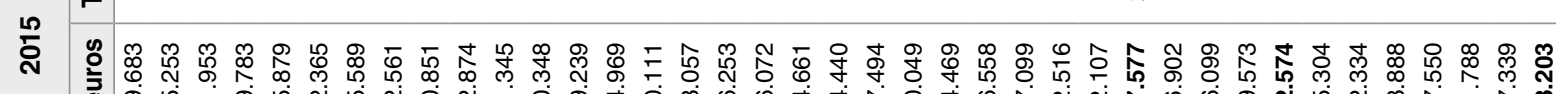

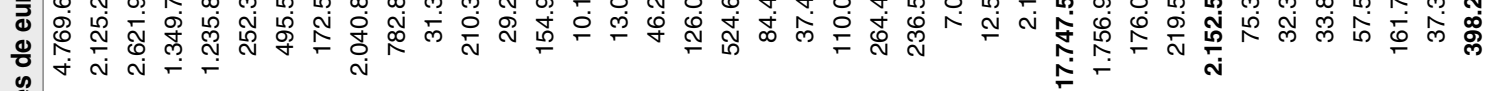

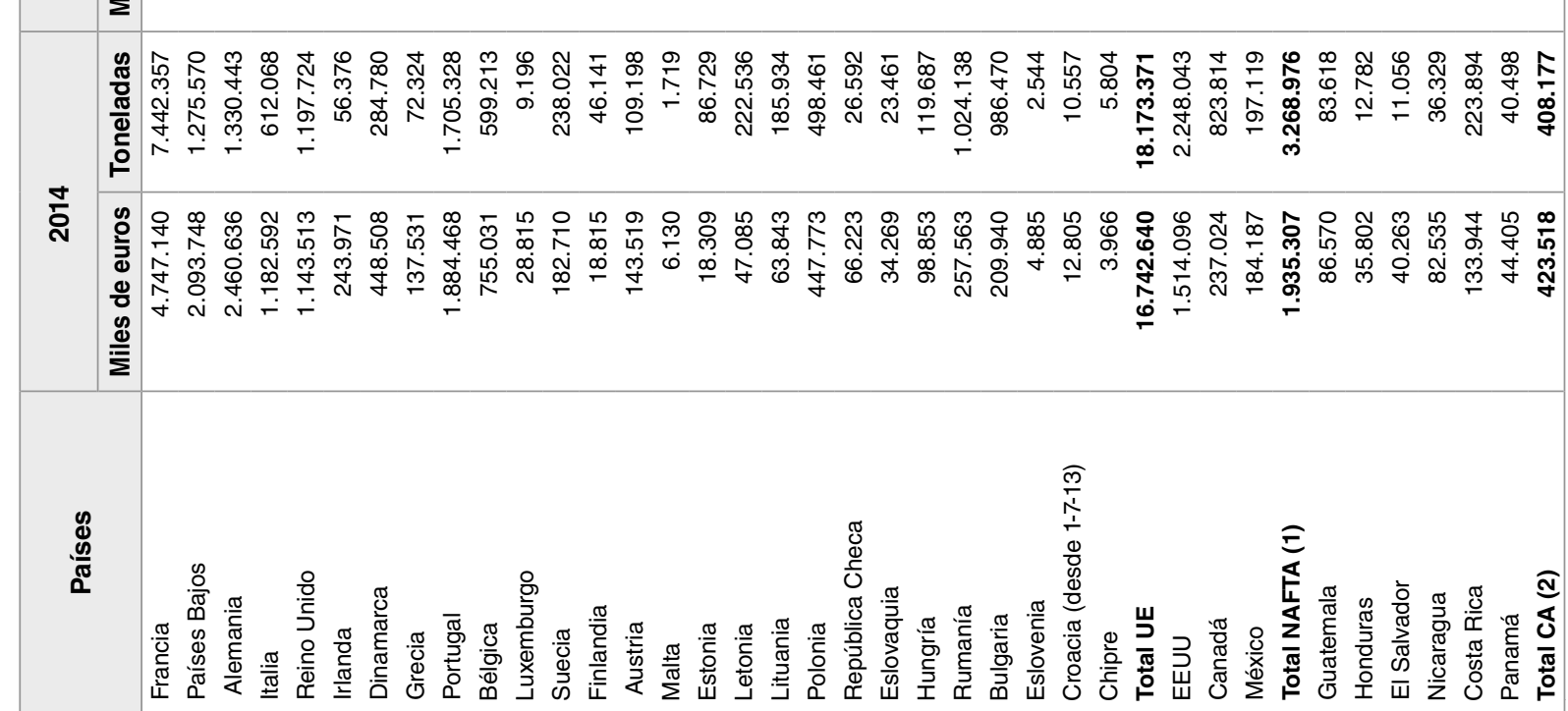

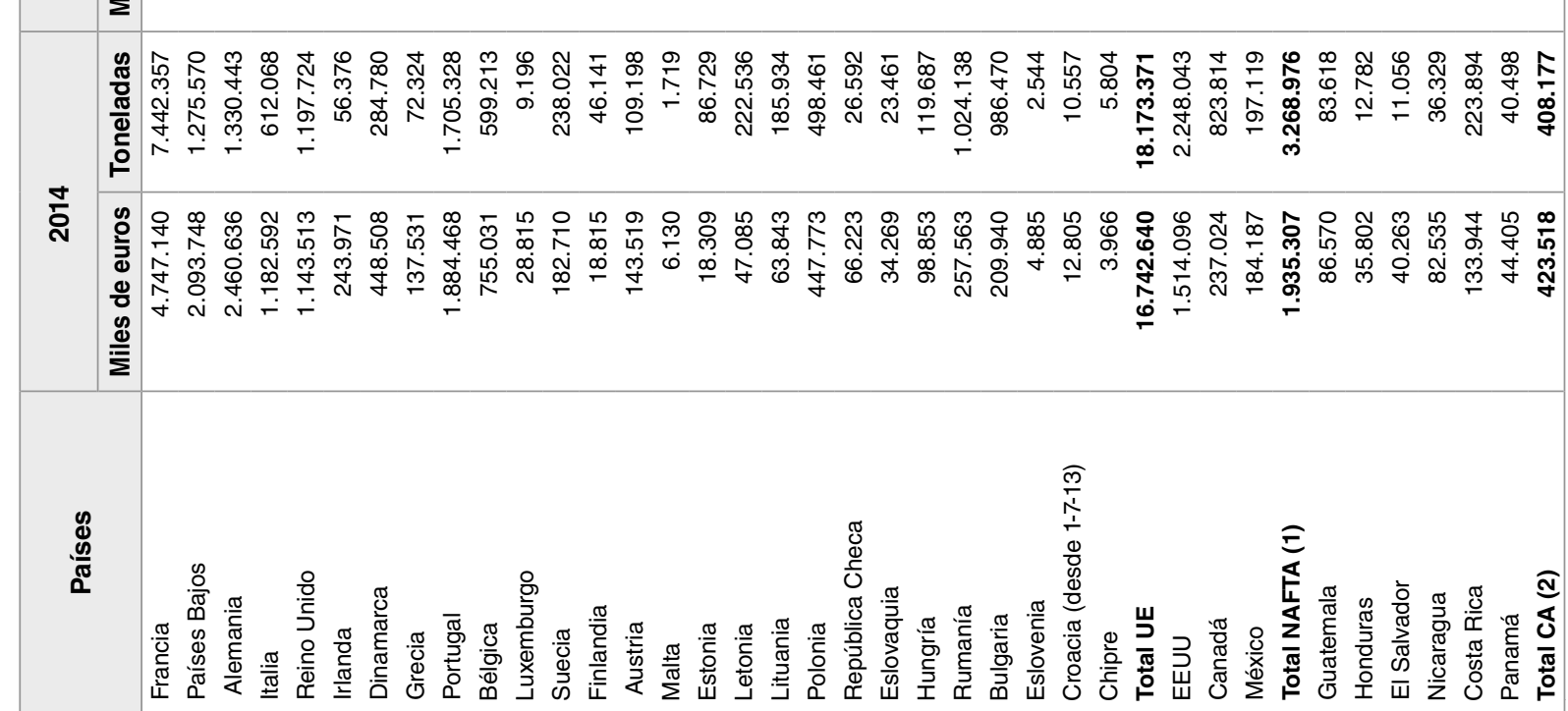

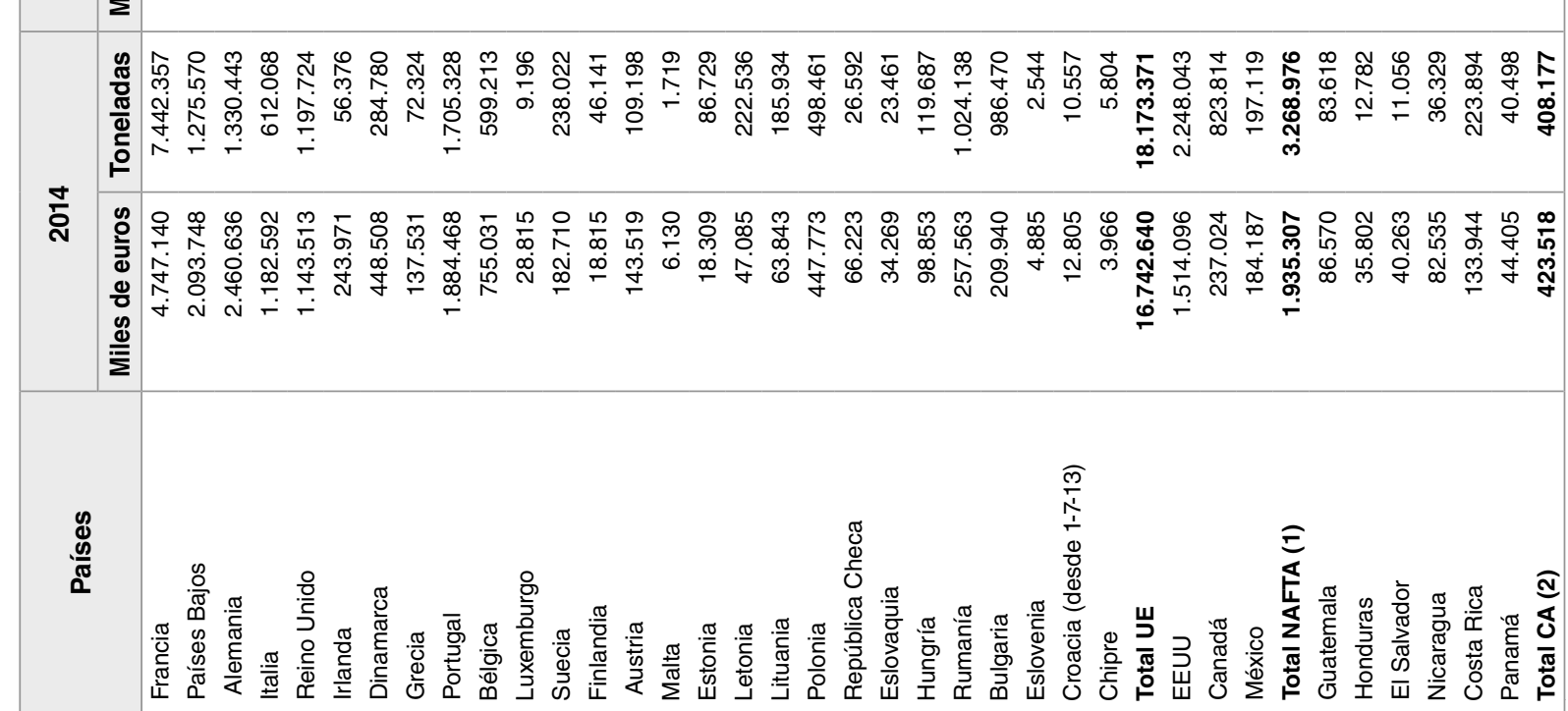

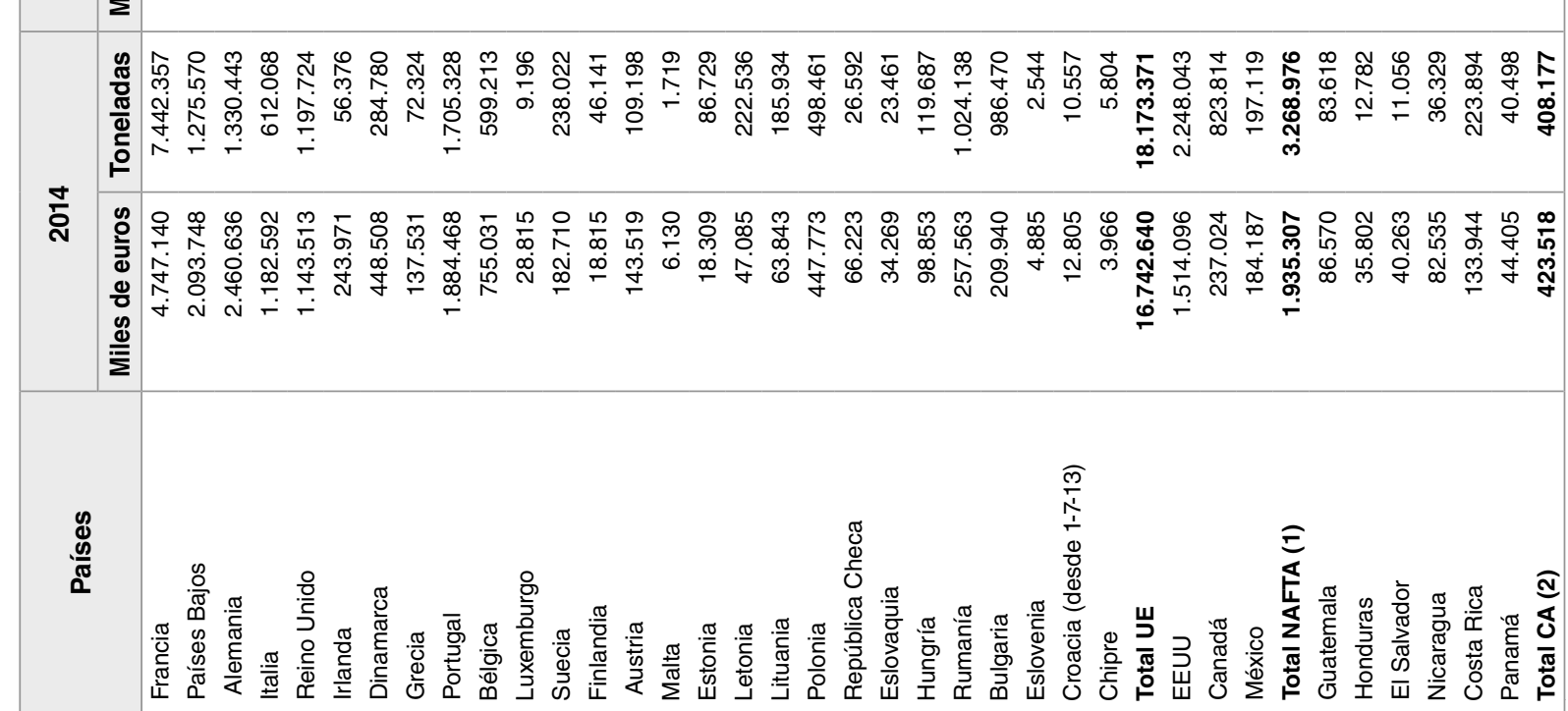

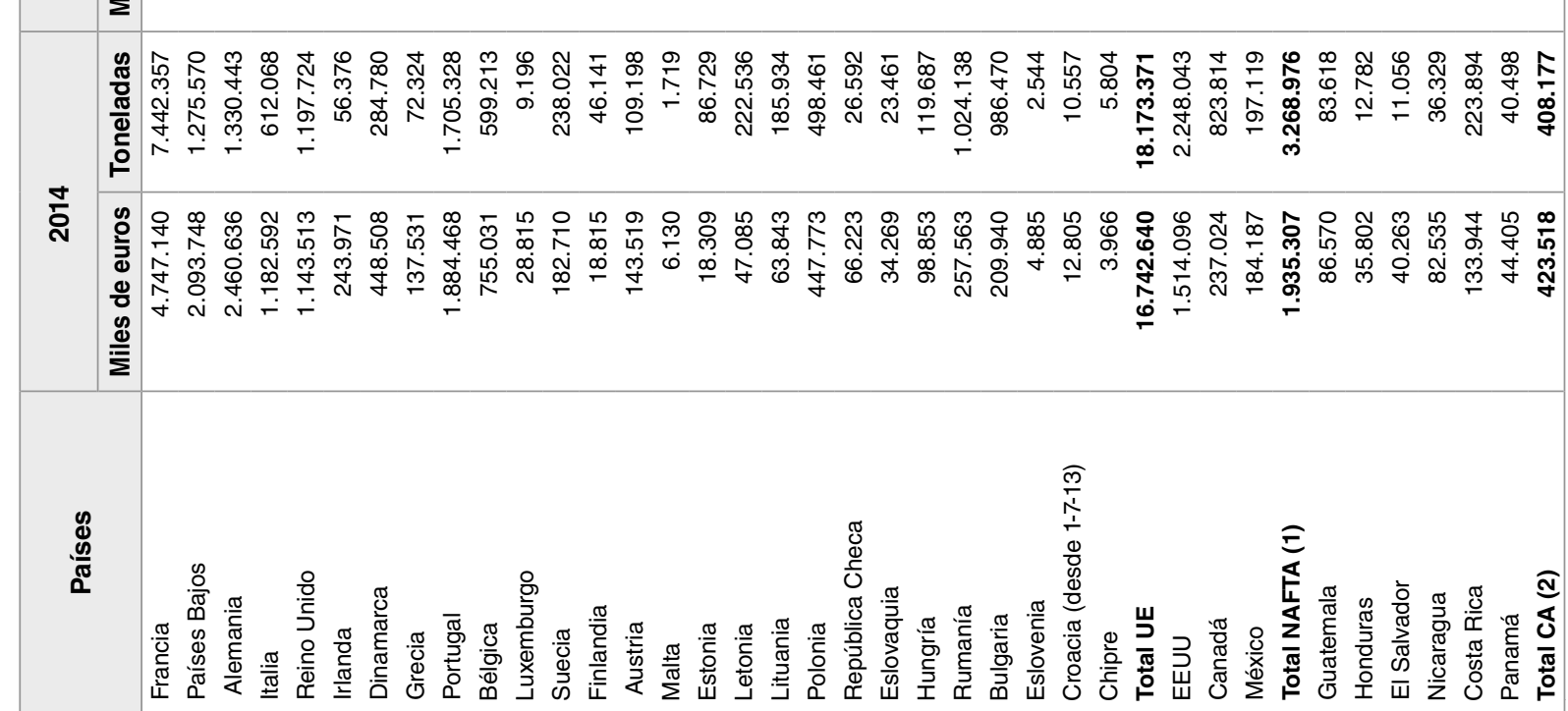




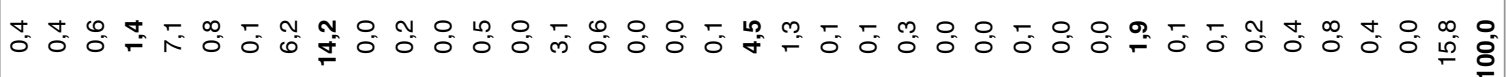

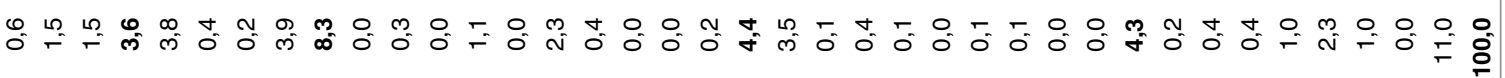

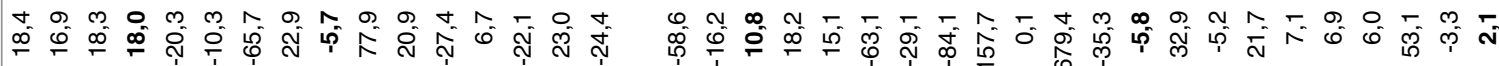
लि

等

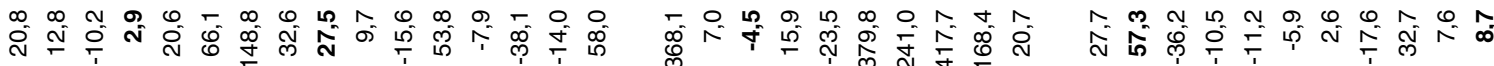

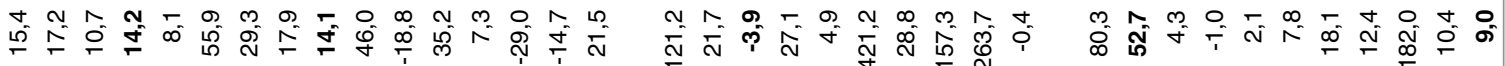

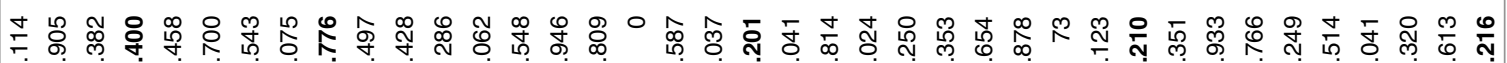

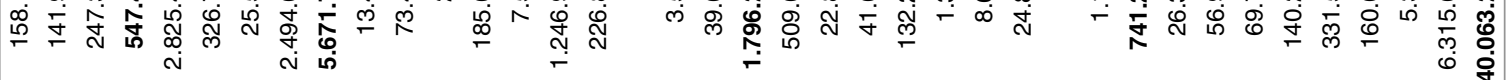

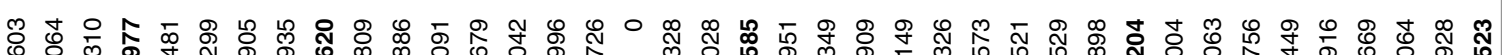

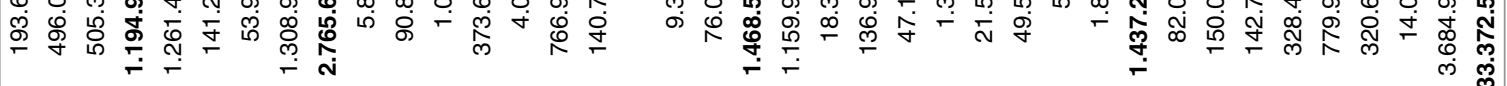

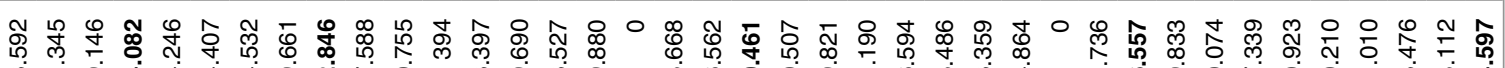

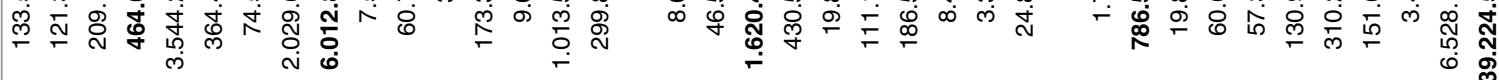

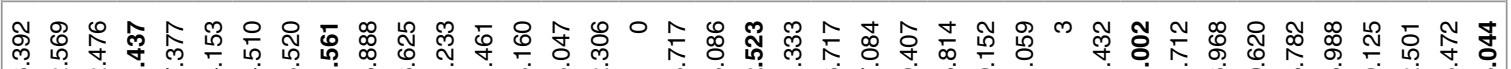

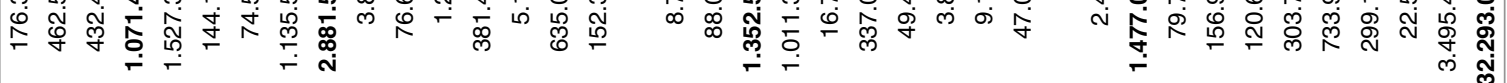

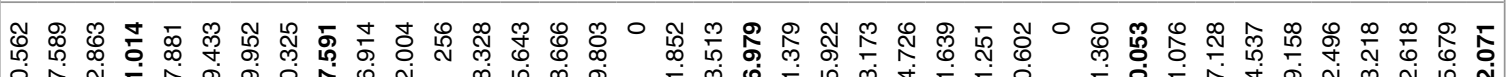

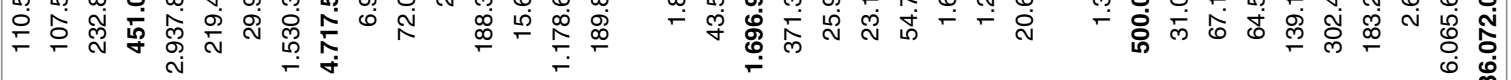

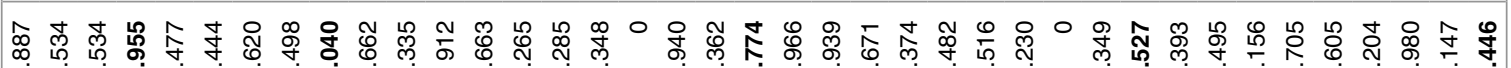

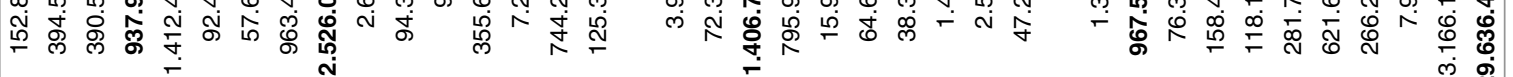


Subdirección General de Comercio Internacional de Productos Agroalimentarios

\section{Análisis sectorial del comercio exterior agroalimentario}

El análisis sectorial se presenta resumido en este artículo. La balanza comercial con el análisis sectorial completo se encuentra en la siguiente página de Internet: $h$ ttp://www.comercio.gob.es/es-ES/comercio-exterior/informacion-sectorial/agroalimentarios/estadisticas/ Paginas/estadisticas.aspx

El Cuadro 6 permite tener una visión de conjunto del comercio exterior por sectores.

CUADRO 6

BALANZA COMERCIAL AGROALIMENTARIA POR SECTORES

(Miles de euros)

\begin{tabular}{|c|c|c|c|c|c|c|c|c|}
\hline \multirow{2}{*}{ Descripción } & \multicolumn{3}{|c|}{2015} & \multicolumn{3}{|c|}{2016} & \multicolumn{2}{|c|}{ \% variación 2016/2015 } \\
\hline & Exportación & Importación & Saldo & Exportación & Importación & Saldo & Exportación & Importación \\
\hline Cárnicos & 5.880 .053 & 2.070 .423 & 3.809 .630 & 6.573 .798 & 2.096 .150 & 4.477 .648 & 11,8 & 1,2 \\
\hline Bovino & 814.282 & 847.219 & -32.937 & 864.704 & 914.552 & -49.848 & 6,2 & 7,9 \\
\hline Ovino-caprino & 274.905 & 81.699 & 193.206 & 306.863 & 72.850 & 234.013 & 11,6 & $-10,8$ \\
\hline Porcino & 4.022 .894 & 504.407 & 3.518 .487 & 4.679 .654 & 466.406 & 4.213 .248 & 16,3 & $-7,5$ \\
\hline Aves y huevos & 644.366 & 569.065 & 75.301 & 596.067 & 573.946 & 22.121 & $-7,5$ & 0,9 \\
\hline Otros animales & 123.606 & 68.033 & 55.573 & 126.510 & 68.396 & 58.114 & 2,3 & 0,5 \\
\hline Lácteos & 939.998 & 1.551 .579 & -611.581 & 958.393 & 1.466 .250 & -507.857 & 2,0 & $-5,5$ \\
\hline Pesca & 3.243 .616 & 5.740 .818 & -2.497 .202 & 3.563 .889 & 6.340 .088 & -2.776 .199 & 9,9 & 10,4 \\
\hline Cereales y prod. de la molinería & 665.018 & 2.950 .179 & -2.285 .161 & 591.951 & 2.881 .479 & -2.289 .528 & $-11,0$ & $-2,3$ \\
\hline Res. de ind. alimentaria y piensos & 944.145 & 1.824 .842 & -880.697 & 962.986 & 1.730 .235 & -767.249 & 2,0 & $-5,2$ \\
\hline Flores y plantas & 289.834 & 185.965 & 103.869 & 325.263 & 209.294 & 115.969 & 12,2 & 12,5 \\
\hline Hortalizas y legumbres & 5.416 .501 & 1.037 .838 & 4.378 .663 & 5.866 .488 & 1.150 .294 & 4.716 .194 & 8,3 & 10,8 \\
\hline Frutas & 8.219 .415 & 2.516 .024 & 5.703 .391 & 8.182 .406 & 2.687 .953 & 5.494 .453 & $-0,5$ & 6,8 \\
\hline Conservas vegetales & 2.511 .113 & 1.064 .820 & 1.446 .293 & 2.634 .789 & 1.178 .500 & 1.456 .289 & 4,9 & 10,7 \\
\hline Vinos, bebidas y vinagre & 4.095 .356 & 1.784 .531 & 2.310 .825 & 4.019 .015 & 1.808 .391 & 2.210 .624 & $-1,9$ & 1,3 \\
\hline Tabaco & 256.302 & 1.514 .382 & -1.258 .080 & 246.449 & 1.474 .801 & -1.228 .352 & $-3,8$ & $-2,6$ \\
\hline Grasas y aceites & 3.632 .249 & 2.229 .013 & 1.403 .236 & 4.219 .673 & 2.299 .944 & 1.919 .729 & 16,2 & 3,2 \\
\hline S. oleaginosas, mandioca y forraje & 576.359 & 2.145 .613 & -1.569 .254 & 636.795 & 2.068 .939 & -1.432 .144 & 10,5 & $-3,6$ \\
\hline Café, té, cacao y azúcar & 874.280 & 2.079 .570 & -1.205 .290 & 939.169 & 2.121 .883 & -1.182 .714 & 7,4 & 2,0 \\
\hline Industrias agroalimentarias & 3.988 .653 & 3.356 .059 & 632.594 & 4.266 .856 & 3.599 .030 & 667.826 & 7,0 & 7,2 \\
\hline Otros productos & 524.857 & 2.526 .550 & -4.951 .871 & 553.814 & 259.292 & 294.522 & 5,5 & $-89,7$ \\
\hline Total & 42.057 .749 & 32.293.044 & 9.764 .705 & 44.541 .734 & 33.372 .523 & 11.169.211 & 5,9 & 3,3 \\
\hline
\end{tabular}

